\title{
FLORISTIC-STRUCTURAL VARIATION OF NATURAL REGENERATION ALONG DIFFERENT TOPOGRAPHIC POSITIONS OF AN ECOTONAL FOREST IN SANTA CATARINA, BRAZIL'
}

\author{
Chayane Cristina de Souza ${ }^{2}$, Pedro Higuchi ${ }^{3 *}$, Ana Carolina da Silva ${ }^{3}$, Karine Souza ${ }^{2}$, Angélica Dalla \\ Rosa $^{4}$, Carla Carolina Chini Rech ${ }^{2}$, Luiz Carlos Rodrigues Junior ${ }^{4}$ and Felipe Fornara Walter ${ }^{4}$
}

\footnotetext{
${ }^{1}$ Received on 04.08.2015 accepted for publication on 03.05.2017.

${ }^{2}$ Universidade do Estado de Santa Catarina, Programa de Pós-Graduação em Engenharia Florestal. E-mail: $<$ chayanesouza8@gmail.con>,<karisouza@hotmail.com>and <karol_chini@hotmail.com>.

${ }^{3}$ Universidade do Estado de Santa Catarina, Departamento de Engenharia Florestal. E-mail: < higuchip@gmail.com> and <carol_sil4@yahoo.com.br>.

${ }^{4}$ Universidade do Estado de Santa Catarina,Graduando em Engenharia Florestal,Lages,SC,Brasil. E-mail:<angelica.dalla.rosa@hotmail.com>, $<$ luiz.crj@hotmail.com> and < felipewalterr@hotmail.com>.

*Corresponding author.
}

\begin{abstract}
Studies on the natural regeneration of tree species communities are important for providing information on forest development capacity. This research aimed to evaluate the floristic-structural variations of the tree regenerative component along a topographic gradient in an ecotonal area between a Mixed Ombrophilous Forest and a Deciduous Seasonal Forest of Santa Catarina, Brazil. 30 sampling units of which all regenerating tree species individuals have been identified were allocated in the forest fragment. The sampling units were then distributed along a topographic gradient into lower, intermediate and upper sectors. Abundance, richness, Shannon's diversity index (H') and Pielou's evenness index (J) have been determined for both the whole community as for each sector. The community floristic-structural organization was verified by the means of the nonmetric multidimensional scaling (NMDS), the indicator species analysis and the permutational multivariate analysis of variance (PERMANOVA). Abundance differences among sectors were analyzed through the KruskalWallis test with post hoc multiple nonparametric test while richness differences were verified through rarefaction. Regenerating individuals density in the upper sector [129 $\left(21.300\right.$ ind.ha $\left.\left.^{-1}\right)\right]$ was lower than both in the lower

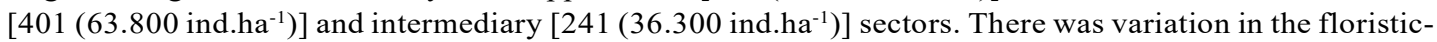
structural composition $(p<0.001)$ among topographic positions; the lower sector was the most distinct one and showed the highest number of indicator species.
\end{abstract}

Keywords: Regenerative component; Toposequence; NMDS.

\section{VARIAÇÃO FLORÍSTICO-ESTRUTURAL DA REGENERAÇÃO NATURAL EM DIFERENTES POSIÇÕES TOPOGRÁFICAS EM UMA FLORESTA ECOTONAL EM SANTA CATARINA}

\begin{abstract}
RESUMO - Estudos sobre a regeneração natural de comunidades de espécies arbóreas são importantes por fornecer informações sobre a capacidade de desenvolvimento da floresta. O presente trabalho objetivou avaliar as variações florístico-estruturais do componente arbóreo regenerativo ao longo de um gradiente topográfico, em uma área ecotonal entre Floresta Ombrófila Mista e Floresta Estacional Decidual em Santa Catarina. No fragmento florestal, foram instaladas 30 unidades amostrais, onde todos os individuos arbóreos regenerantes foram identificados. As unidades amostrais foram distribuídas em três setores ao longo de um gradiente topográfico: setor inferior, intermediário e superior. Para a comunidade como um todo e para cada setor, foram determinados a abundância, riqueza, indice de Shannon (H') e equabilidade de Pielou (J). A organização florístico-estrutural da comunidade foi verificada por meio do Escalonamento Multidimensional Não-Métrico (NMDS), análise de espécies indicadoras e Análise de Variância Multivariada Permutacional (PERMANOVA). Diferenças de abundância e riqueza entre os setores foram avaliadas, respectivamente, pela Análise de KruskalWallis, com teste múltiplo não paramétrico, e rarefação. Houve baixa densidade de indivíduos regenerante
\end{abstract}


inferior e 241 (36.300 ind.ha ${ }^{-1}$ ) no intermediário]. Observou-se que a composição florístico-estrutural foi variável entre as posições topográficas $(\mathrm{p}<0,001)$, sendo o setor inferior o mais distinto dos demais e com maior número de espécies indicadoras.

Palavras-Chave: Componente regenerativo; Topossequência; NMDS.

\section{INTRODUCTION}

The southern Brazil Atlantic forest has different formations, such as the Mixed Ombrophilous Forest (MOF) occurring at generally higher than $500 \mathrm{~m}$ altitudes and the Deciduous Seasonal Forest (DSF) occurring from 150 to $800 \mathrm{~m}$ high (Klein, 1978). In the altitudes where they overlap their contact results in the formation of ecotone areas. These ecotonal areas are not homogeneous and may be influenced by a number of local physical factors, such as edaphic and topographic variations.

A high terrain variation is observed in the ecotonal areas of the Upper Uruguay region where rivers are known for draining into "steep" valleys. In such places, there is a sequence of different types of soils spread along the landscape according to topography (Cunha et al., 2009). The organization of both adult and regenerating tree species communities developing in such environments are conditioned in a small spatial scale by environmental factors related to topographic gradients (Rodrigues et al., 2007; Scipioni et al., 2009; Budke et al., 2010; Souza et al., 2015; Braga et al., 2015; Guo et al., 2017; Mohammadi et al., 2017). According to Gandolfi (2000) and Jafari et al. (2003) this happens because declivity acts as a factor that produces a variety of environmental situations in soil particle transport and vertical canopy organization, such as moisture gradient. That explains the importance of topographic variations on the organization of tree vegetation, as reported in former studies (Rodrigues et al., 2007; Braga et al., 2015), including the adult component of the same area (Souza et al., 2015).

One of the most critical phases for the establishment of tree species in forest communities refers to their regeneration stage under the understory condition (Kitajima and Fenner, 2000; Poorter, 2007). Studies aiming to deepen the knowledge on the factors that influence this stage are therefore relevant as they allow a better understanding on the development of a forest under natural conditions. Upper Uruguay stands out among the Brazilian southern regions where studies of this nature are necessary for subsidizing both conservation and restoration strategies since its forests face a critical status of conservation due to its selective exploration and forest fragmentation history. In this sense, the main goal of this study was to investigate the floristicstructural organization of the regenerative component according to its topographic position in an ecotonal area between the Mixed Ombrophylous Forest and the Deciduous Seasonal Forest of Santa Catarina, Brazil. Considering the topographic gradient, a high floristicstructural variation is expected thus reinforcing the importance of conserving different microhabitats in a forest under such conditions.

\section{MATERIALAND METHODS}

The study was conducted in an advanced successional stage area previously inventoried (adult tree component) by Souza et al. (2015). It is an ecotonal area between the Mixed Ombrophilous Forest and the Deciduous Seasonal Forest in the municipality of Capão Alto, SC, Brazil (28 $11^{\prime} 29^{\prime \prime S}$ and 50'45'34"L and altitude about 600 to $700 \mathrm{~m}$ ). Its topography varies mainly from smooth to gentle slopes and its higher-sloped areas are near the main rivers of the region therefore forming steep valleys located in the sandstone-basalt plateau. It has a Cfa climate according to Köppen classification and its average annual rainfall varies from 1,200 to $1,900 \mathrm{~mm}$ well distributed along the year. According to the CRU CL 2.0 database (New et al., 2002) the average temperatures of its coldest and hottest months in the last 30 years $(1985-2015)$ were $12.0^{\circ} \mathrm{C}$ in July and $20.7^{\circ} \mathrm{C}$ in January, respectively (Grechka et al., 2016).

Data were collected in a hillside on the banks of the Barra Grande dam on Pelotas River, which reservoir is formed since 2005. Three sectors have been defined for the area: lower sector (near the generally less-sloped reservoir bank which shows moisture and areas subject to flooding), intermediate sector (highly sloped in the middle of the hillside), and upper sector (also highly sloped but at the top of the hillside). Each sector's slope was measured by Souza et al. (2015) who have observed about $14.38^{\circ}( \pm 2.64), 19.74^{\circ}( \pm 1.98)$ and $20.66^{\circ}$ $( \pm 1.24)$ for the lower, intermediate and upper sectors, respectively.

Revista Árvore. 2017;41(3):e410305 
For characterizing the regenerative tree component (DBH lower than $5 \mathrm{~cm}$ and height higher or equal to $20 \mathrm{~cm}$ ) we have used part of the plots allocated by Souza et al. (2015) - who have carried out a stratifiedsystematic sampling with $200 \mathrm{~m}^{2}$ plots spaced $10 \mathrm{~m}$ apart from each other - for sampling the adult tree component (DBH higher than or equal to $5 \mathrm{~cm}$ ). We have used 10 plots allocated in each of the three sectors, making 30 allocated plots (Figure 1) which were subdivided into different sized subplots according to the regenerating tree species height classification. Each smaller subplot was allocated within a larger plot according to Volpato's methodology (Volpato, 1994). Thus, the regenerating tree species class 1 has consisted of $20 \mathrm{~cm}$ to $1 \mathrm{~m}$ high plants sampled in $5 \mathrm{~m}^{2}$ subplots; the class 2 has consisted of above 1 to $3 \mathrm{~m}$ high plants sampled in $10 \mathrm{~m}^{2}$ subplots; and the class 3 has consisted of more than $3 \mathrm{~m}$ high plants with DBH less than 5 cm sampled in $20 \mathrm{~m}^{2}$ subplots.

Regenerating individuals were tagged with metal tags so as to register each plant's height class. The individuals were collected and identified through both the literature and experts support. Species were classified by families arranged according to the APG III system (Angiosperm Phylogeny Group, 2009) so that their spellings were verified in the Brazilian Flora Species List website (http://floradobrasil.jbrj.gov.br/).

For data analysis, the species were arranged according to their presence and density in the sampling plots of all three sectors (lower, intermediate and upper). Abundance, Shannon diversity index ( $\left.\mathrm{H}^{\prime}\right)$ and Pielou's evenness index $(\mathrm{J})$ were determined for each sector in order to analyze the existence of spatial heterogeneity of structural and diversity patterns due to environmental compartmentalization. Abundance values were evaluated for normality (Shapiro-Wilk test) and if data did not show normal distribution they were compared among sectors through the Kruskal-Wallis test followed by a post hoc nonparametric multiple test so the hypothesis of structural variation among sectors was tested. Richness was compared by the rarefaction technique in order to test the species number variation hypothesis according to topographic position. A multivariate ordering of non-metric multidimensional scaling (NMDS) type was performed by using Bray-Curtis as floristicstructural distance, from a species' abundance matrix related to each sector's plots, to verify the existence of floristic-structural composition variations due to

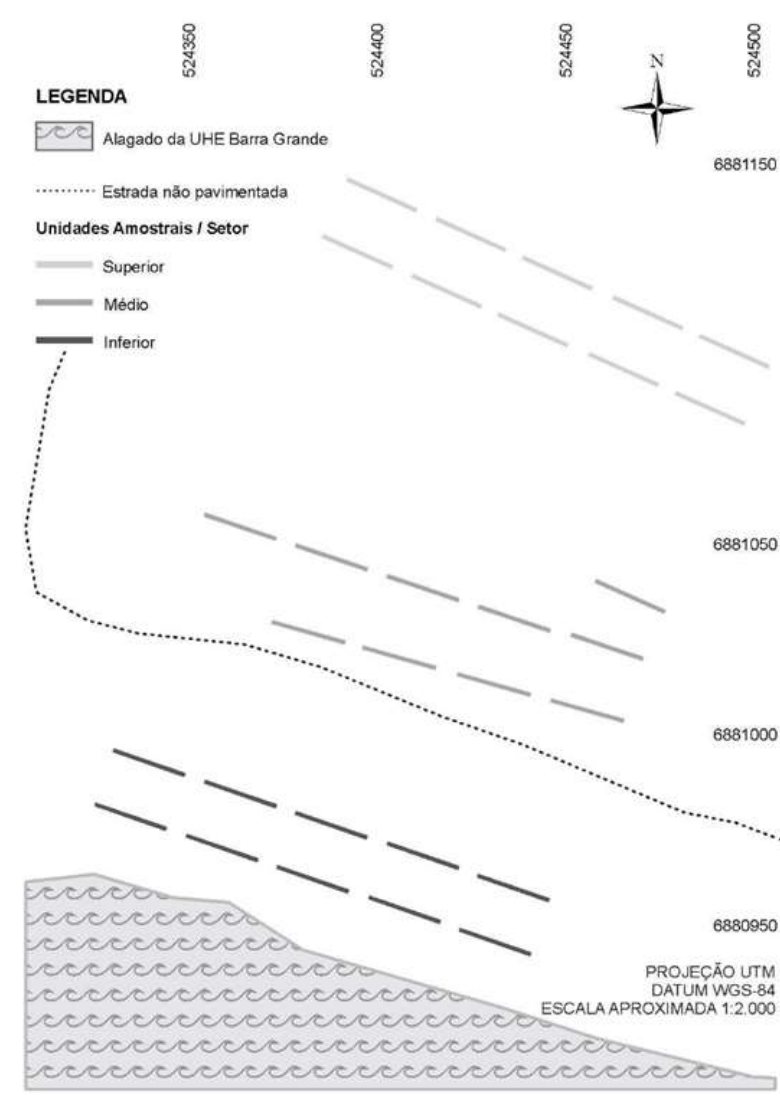

Figure 1 - Sample units' spatial distribution in the three sectors (lower, intermediate and upper) in a fragment of a transitional area between the Mixed Ombrophilous Forest and the Seasonal Deciduous Forest in the municipality of Capão Alto, Santa Catarina, Brazil.

Figura 1-Distribuição espacial das unidades amostrais nos três setores (inferior, intermediário e superior) em um fragmento em área de transição entre Floresta Ombrófila Mista e Floresta Estacional Decidual no município de Capão Alto, em Santa Catarina.

topographic position. A nonparametric multivariate analysis of variance (NPMANOVA) was held through the same data matrix used in the NMDS in order to test the hypothesis of community variation in relation to topographic position. An indicator species analysis (IndVal) was carried out with the species' abundance matrix according to each sector's plots for verifying the existence of species associated to the sectors. All analyzes were held by the means of the statistical programming language $\mathrm{R}$ ( $\mathrm{R}$ Development Core Team, 2015) together with the vegan (Oksanen et al., 2015) and labdsv (Roberts, 2015) packages.

Revista Árvore. 2017;41(3):e410305 


\section{RESULTS}

A total of 771 individuals were sampled in 24 botanical families, 42 genera and 51 species along the different topographic positions (Table 1). One individual has not been identified for being too young for collection. The regenerating tree species abundance did not occur homogeneously along the hillside; the lower sector has shown more than half of the individuals [401 (251 from class 1 in $50 \mathrm{~m}^{2}, 122$ from class 2 in $100 \mathrm{~m}^{2}$, and 28 from class 3 in $200 \mathrm{~m}^{2}$ )] which has significantly differed from the upper sector which has shown only $16.8 \%$ sampled individuals.

Likewise, variations in richness and diversity were observed along the topographic gradient so that the lower sector has shown the lowest diversity (2.63), evenness (0.75) and standardized richness (23.12). This pattern has reflected in the ordering produced by the NMDS, which has shown a 0.18 stress value therefore indicating that the analysis was adequate for ecological interpretations. In the ordering, one can notice that the lower sector, which has shown the lowest diversity and the highest abundance and ecological dominance, has also been the most distinct and homogeneous from the floristic-structural point of view since its plots have shown the lowest dispersion (Figure 2). These differences in the lower sector are indicated by the segregation relative to the plots of the other two sectors along the NMDS axis 2 , which significance $(\mathrm{p}<0.001)$ has been confirmed by NPMANOVA.

Some species are widely distributed along the area, such as Cupania vernalis Cambess., which has occurred in all sectors. However, nine indicator species have been observed, mainly in the lower sector (six) (Table 2). The intermediate and upper sectors had only two and one indicator species, respectively. Results are in line with the multivariate ordering thus indicating a higher floristic-structural distinction in the lower sector.

\section{DISCUSSION}

Results show that the environmental compartmentalization related to the terrain has proved to be an important source of floristic-structural heterogeneity for the regenerative component where the lower sector turned out to be the most distinct one in comparison to the other two sectors by showing the highest number of indicator species as well as the highest abundance with more than half of all 771 sampled

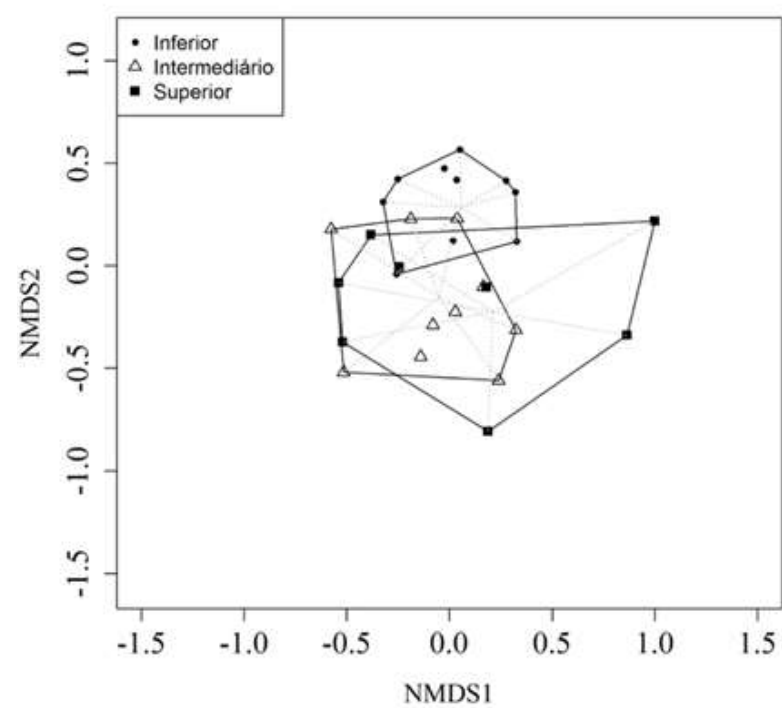

Figure 2 - Non-metric multidimensional scaling (NMDS) for species and sectors in a fragment of a transitional area between Mixed Ombrophilous Forest and Seasonal Deciduous Forest in the municipality of Capão Alto, Santa Catarina, Brazil.

Figura 2-Escalonamento Multidimensional Não-Métrico (NMDS) para as espécies e setores de um fragmento em área de transição entre Floresta Ombrófila Mista e Floresta Estacional Decidual no municipio de Capão Alto, em Santa Catarina.

individuals $\left(121,400\right.$ ind.ha $\left.{ }^{-1}\right)-$ which have opposed its low richness, diversity and evenness. Variations in environmental conditions due to topographic sectors may have influenced diversity patterns in different ways, such as: i) the existence of more selective environmental conditions in the lower sector therefore causing its low richness and the dominance of a group of adapted species; (ii) on the opposite side, the lower sector may show better environmental conditions (e.g. a higher fertility) so that ecological dominance results from the competitive exclusion for species more efficient in acquiring resources; and iii) a higher environmental heterogeneity in the intermediate and upper sectors, such as the presence of gaps, resulting in a larger distribution spectrum of species from different ecological groups.

The spatial heterogeneity in the abundance distribution of tree species individuals is a common behavior in forest ecosystems (Hubbel et al., 1999; Pitman et al., 1999) and results from a complex interaction

Revista Árvore. 2017;41(3):e410305 
Floristic-structural variation of natural...

Table 1 - Number of individuals sampled for each species and sector $($ Low $=$ lower; Int $=$ intermediate; Upp $=$ upper; $\mathrm{T}$ = whole community) in a fragment of a transitional area between the Mixed Ombrophilous Forest and the Seasonal Deciduous Forest in the municipality of Capão Alto, Santa Catarina, Brazil.

Tabela 1 - Número de individuos amostrados para cada espécie e setor (Low = inferior; Int = intermediário; Upp = superior; $T=$ toda a comunidade), em um fragmento em área de transição entre Floresta Ombrófila Mista e Floresta Estacional Decidual no município de Capão Alto, em Santa Catarina.

\begin{tabular}{|c|c|c|c|c|}
\hline Families/Species & Low & Int & Upp & $\mathrm{T}$ \\
\hline \multicolumn{5}{|l|}{ ANNONACEAE } \\
\hline Annona neosalicifolia H.Rainer & 3 & 0 & 0 & 3 \\
\hline Annona rugulosa (Schltdl.) H.Rainer & 1 & 7 & 0 & 8 \\
\hline \multicolumn{5}{|l|}{ APOCYNACEAE } \\
\hline Aspidosperma australe Müll.Arg. & 0 & 1 & 0 & 1 \\
\hline \multicolumn{5}{|l|}{ ARALIACEAE } \\
\hline Oreopanax fulvus Marchal & 0 & 0 & 1 & 1 \\
\hline \multicolumn{5}{|l|}{ ARAUCARIACEAE } \\
\hline Araucaria angustifolia (Bertol.) Kuntze & 2 & 1 & 0 & 3 \\
\hline \multicolumn{5}{|l|}{ ASTERACEAE } \\
\hline Moquiniastrum polymorphum (Less.) G. Sancho & 6 & 0 & 0 & 6 \\
\hline \multicolumn{5}{|l|}{ CARDIOPTERIDACEAE } \\
\hline Citronella gongonha (Mart.) R.A.Howard & 0 & 1 & 0 & 1 \\
\hline \multicolumn{5}{|l|}{ CELASTRACEAE } \\
\hline Maytenus aquifolia Mart. & 0 & 0 & 7 & 7 \\
\hline Schaefferia argentinensis Speg. & 3 & 1 & 6 & 10 \\
\hline \multicolumn{5}{|l|}{ EUPHORBIACEAE } \\
\hline Gymnanthes klotzschiana Müll.Arg. & 3 & 1 & 0 & 4 \\
\hline Sebastiania brasiliensis Spreng. & 0 & 15 & 12 & 27 \\
\hline \multicolumn{5}{|l|}{ FABACEAE } \\
\hline Dalbergia frutescens (Vell.) Britton & 1 & 4 & 0 & 5 \\
\hline Machaerium paraguariense Hassl. & 2 & 6 & 1 & 9 \\
\hline Muellera campestris (Mart. ex Benth.) M.J. Silva \& A.M.G. Azevedo & 10 & 4 & 3 & 17 \\
\hline Myrocarpus frondosus Allemão & 0 & 1 & 2 & 3 \\
\hline Parapiptadenia rigida (Benth.) Brenan & 10 & 17 & 3 & 30 \\
\hline INDERTEMINED & 0 & 0 & 1 & 1 \\
\hline \multicolumn{5}{|l|}{ LAURACEAE } \\
\hline Nectandra megapotamica (Spreng.) Mez & 96 & 19 & 17 & 132 \\
\hline Ocotea puberula (Rich.) Nees & 25 & 0 & 0 & 25 \\
\hline Ocotea pulchella (Nees \& Mart.) Mez & 1 & 1 & 1 & 3 \\
\hline Ocotea sp. 12 & 0 & 0 & 2 & \\
\hline Ocotea sp. 20 & 1 & 0 & 1 & \\
\hline \multicolumn{5}{|l|}{ MELIACEAE } \\
\hline Cedrela fissilis Vell. & 0 & 0 & 1 & 1 \\
\hline Trichilia elegans A.Juss. & 8 & 40 & 11 & 59 \\
\hline \multicolumn{5}{|l|}{ MYRTACEAE } \\
\hline Blepharocalyx salicifolius (Kunth) O.Berg & 5 & 5 & 1 & 11 \\
\hline Calyptranthes concinna DC. & 0 & 1 & 0 & 1 \\
\hline Campomanesia xanthocarpa (Mart.) O.Berg & 34 & 9 & 2 & 45 \\
\hline Eugenia uniflora $\mathrm{L}$. & 29 & 11 & 4 & 44 \\
\hline Eugenia uruguayensis Cambess. & 1 & 2 & 0 & 3 \\
\hline Myrceugenia mesomischa (Burret) D.Legrand \& Kausel & 1 & 0 & 0 & 1 \\
\hline Myrcianthes gigantea (D.Legrand) D.Legrand & 1 & 4 & 3 & 8 \\
\hline Myrcianthes pungens (O.Berg) D.Legrand & 0 & 3 & 0 & 3 \\
\hline \multicolumn{5}{|l|}{ OLEACEAE } \\
\hline Ligustrum lucidum W.T.Ait.* & 3 & 0 & 0 & 3 \\
\hline
\end{tabular}


Table 1...

Tabela $1 . .$.

PRIMULACEAE

Myrsine coriacea (Sw.) R.Br. ex Roem. \& Schult.

Myrsine lorentziana (Mez) Arechav.

RHAMNACEAE

Scutia buxifolia Reissek

RUBIACEAE

Coutarea hexandra (Jacq.) K.Schum.

Rudgea parquioides (Cham.) Müll.Arg.

RUTACEAE

Pilocarpus pennatifolius Lem.

SALICACEAE

Banara tomentosa Clos

Casearia decandra Jacq.

SAPINDACEAE

Allophylus edulis (A.St.-Hil. et al.) Hieron. ex Niederl.

Allophylus guaraniticus (A.St.-Hil.) Radlk.

Cupania vernalis Cambess.

Matayba elaeagnoides Radlk.

SOLANACEAE

Brunfelsia cuneifolia J.A.Schmidt

Cestrum intermedium Sendtn.

Solanum pseudoquina A.St.-Hil.

STYRACACEAE

Styrax leprosus Hook. \& Arn.

VERBENACEAE

Duranta vestita Cham.

Total of individuals (total per hectare)

Richness

Richness measured by rarefaction

Shannon (H')

Pielou (J)

\begin{tabular}{|c|c|c|c|}
\hline 0 & 3 & 1 & 4 \\
\hline 0 & 0 & 1 & 1 \\
\hline 1 & 0 & 0 & 1 \\
\hline 0 & 14 & 2 & 16 \\
\hline 0 & 0 & 1 & 1 \\
\hline 0 & 3 & 8 & 11 \\
\hline 6 & 2 & 1 & 9 \\
\hline 2 & 1 & 2 & 5 \\
\hline 62 & 20 & 8 & 90 \\
\hline 22 & 11 & 9 & 42 \\
\hline 33 & 16 & 16 & 65 \\
\hline 17 & 5 & 2 & 24 \\
\hline 4 & 2 & 0 & 6 \\
\hline 1 & 0 & 0 & 1 \\
\hline 2 & 0 & 0 & 2 \\
\hline 4 & 8 & 0 & 12 \\
\hline 0 & 0 & 1 & 1 \\
\hline $\begin{array}{l}401^{\mathrm{a}} \\
(63800)\end{array}$ & $\begin{array}{c}241^{\mathrm{ab}} \\
(36300)\end{array}$ & $\begin{array}{l}129^{b} \\
(21300)\end{array}$ & $\begin{array}{c}771 \\
(121400)\end{array}$ \\
\hline 33 & 35 & 29 & 51 \\
\hline 23.12 & 28.68 & 29 & - \\
\hline 2.63 & 3.02 & 2.91 & 3.06 \\
\hline 0.75 & 0.85 & 0.86 & 0.78 \\
\hline
\end{tabular}

${ }^{*}$ Exotic species. The values of total individuals by sector followed by different letters indicate significant differences by the nonparametric multiple test applied after the Kruskal-Wallis test.

Table 2 - Indicator species of the regenerative component for each topographic sector in a fragment of a transitional area between the Mixed Ombrophilous Forest and the Seasonal Deciduous Forest in the municipality of Capão Alto, Santa Catarina, Brazil.

Tabela 2 - Espécies indicadoras do componente regenerativo para cada setor topográfico, em um fragmento em área de transição entre Floresta Ombrófila Mista e Floresta Estacional Decidual no município de Capão Alto, em Santa Catarina.

\begin{tabular}{lc}
\hline Indicator Species & Class \\
\hline Allophylus edulis & Lower \\
Campomanesia xanthocarpa & Lower \\
Nectandra megapotamica & Lower \\
Eugenia uniflora & Lower \\
Matayba elaeagnoides & Lower \\
Ocotea puberula & Lower \\
Trichilia elegans & Intermediary \\
Annona rugulosa & Intermediary \\
Maytenus aquifolia & Upper \\
\hline
\end{tabular}

Revista Árvore. 2017;41(3):e410305 
between several ecological factors, which is related to both the species characteristics and the habitat's quality. For instance, the high density in the lower sector suggests that the species occurring in this environment, besides producing a high amount of propagules, have found favorable environmental conditions for germinating seeds and forming a bank of young plants. This is supported by the fact that the lower sector's class 1 has shown a higher number of individuals than larger size plant classes. On the other hand, the regeneration process seems to be more limited in the upper sectors due to limiting factors, such as low propagules production and/or not favorable environmental conditions for germinating and establishing young plants.

Some species were common to all sectors, demonstrating the high plasticity in habitats colonization, such as the hygrophilous species Cupania vernalis, which is however capable of supporting high slopes. Its higher ecological plasticity is reinforced by Meyer et al. (2013a,b) who have listed it among the most important species in the regenerative component both in areas of Mixed Ombrophilous Forest and Deciduous Seasonal Forest in Santa Catarina, Brazil. According to Via et al. (1995), high plasticity species adapt to unstable environments therefore increasing its environmental tolerance.

There were nine indicator species, most of which in the lower sector, therefore reinforcing its higher distinction. The indicator species from this sector can be considered as tolerant to water stress since some parts of the area are subject to flooding. In fact, some of these species, such as Campomanesia xanthocarpa (Mart.) O.Berg, Matayba elaeagnoides Radlk. and Eugenia uniflora L., were considered by other authors (Reitz et al., 1983; Lorenzi, 2000; Silva et al., 2007; Narvaes et al., 2008) to be tolerant to soils with excess water. Of the two indicator species from the intermediate sector, Trichilia elegans A.Juss. germinates in shaded places, thriving on wet and hillside soils (Schupp et al., 2002), which explains its place of highest abundance. According to a study by Scipioni et al. (2009) held in FED, Santa Maria, RS, Brazil, Trichila elegans also belongs to the sectors influenced by high slopes. Yet Annona rugulosa (Schltdl.) H. Rainer is considered as an early secondary to late species (Lorenzi, 2000). The representative species from the upper sector, Maytenus aquifolia Mart., usually occurs in well-drained soils typical of hillside tops (Lorenzi, 2000).

\section{CONCLUSION}

It is concluded that the terrain's position is an important source of floristic-structural heterogeneity for the regenerative tree component as far as the small spatial scale under analysis is concerned, where the lower sector has proved to be the most distinct among sectors. Topographic variations probably make room for the existence of micro-habitats due to edaphic and microclimatic factors quality. The presence of indicator tree species in each sector reinforces the idea of considering the floristic groups' terrain position when indicating them in programs for recovering degraded areas.

\section{ACKNOWLEDGMENTS}

We thank to FUMDES for granting a scholarship to the first author of this paper; to $\mathrm{CNPq}$ for providing a research productivity grant to both the second and third authors; and to FAPESC for the financial support granted through the PAP/UDESC program.

\section{REFERENCES}

Angiosperm Phylogeny Group - APG III. An update of the Angiosperm Phylogeny Group classification for the orders and families of flowering plants: APG III. Botanical Journal of the Linnean Society. 2009;161(2):105-21.

Braga AJT, Borges EEL, Martins SV. Influência dos fatores edáficos na variação florística de floresta estacional semidecidual, em Viçosa, MG. Revista Árvore. 2015;39(4):623-33.

Budke JC, Jarenkow JA, Oliveira-Filho AT. Intermediary disturbance increases tree diversity in riverine forest of southern Brazil. Biodiversity and Conservation. 2010;19(8):2371-87.

Cunha NG, Silveira RJC, Koester E, Costa FA, Terres VC, Silva JB et al. Estudo dos solos de municípios do Alto Uruguai, RS. Pelotas: Embrapa Clima Temperado; 2009. (Circular técnica).

Gandolfi S. História natural de uma floresta estacional semidecidual no município de Campinas (São Paulo, Brasil) [tese] Campinas: Universidade Estadual de Campinas; 2000.

Grechka DA, Berezin SB, Emmott S, Lyutsarev V, Smith MJ, Purves DW. Universal, easy access to

Revista Árvore. 2017;41(3):e410305 
geotemporal information: FetchClimate. Ecography, 2016. doi:10.1111/ecog.02321.

Guo Y, Wang B, Li D, Mallik AU, Xiang W, Ding T et al. Effects of topography and spatial processes on structuring tree species composition in a diverse heterogeneous tropical karst seasonal rainforest. Flora. 2017;231:21-8.

Hubbell SP, Foster RB, O’Brien ST, Harms KE, Condit R, Wechsler B et al. Light-gap disturbances, recruitment limitation, and tree diversity in a neotropical forest. Science. 1999;283(5401):554-7.

Jafari M, Zare Chahouki MA, Tavili A, Azarnivand H. Soil-vegetation relationships in Hoz-e-Soltan Region of Qom Province, Iran. Pakistan Journal Nutrition. 2003;2(6):329-34.

Klein RM. Flora ilustrada catarinense: mapa fitogeográfico do Estado de Santa Catarina. V Parte - mapa fitogeográfico. Itajaí: Herbário Barbosa Rodrigues; 1978. 24p.

Kitajima K, Fenner M. Ecology of seedling regeneration. In: Fenner M, editor. Seeds, the ecology of regeneration in plant communities. Wallingford: CABI Publishing; 2000. p.331-59.

Lorenzi H. Árvores brasileiras: manual de identificação e cultivo de plantas arbóreas nativas do Brasil. $3^{\mathrm{a}}$.ed. Nova Odessa: Plantarum; 2000. 352p.

Meyer L, Gasper AL, Sevegnani L, Schorn LA, Vibrans AC, Lingner DV et al. Regeneração natural da Floresta Ombrófila Mista em Santa Catarina. In: Vibrans AC, Sevegnani L, Gasper AL, Lingner DV, editors. Inventário florístico florestal de Santa Catarina: Floresta Ombrófila Mista. Blumenau: Edifurb; 2013a. p.191-222.

Meyer L, Gasper AL, Sevegnani L, Schorn LA, Lingner DV, Vibrans AC, et al. Regeneração natural da Floresta Estacional Decidual em Santa Catarina. In: Vibrans AC, Sevegnani L, Gasper AL, Lingner DV, editors. Inventário florístico florestal de Santa Catarina: Floresta Estacional Decidual. Blumenau: Edifurb; 2013b. p.167-87.

Narvaes IS, Longhi S, Brena D. Florística e classificação da regeneração natural em Floresta
Ombrófila Mista na Floresta Nacional de São Francisco de Paula, RS. Ciência Florestal. 2008;18(2):233-45.

New M, Lister D, Hulme M, Makin I. A highresolution data set of surface climate over global land areas. Climate Research. 2002;21(1):1-25.

Mohammadi MF, Jalali SG, Kooch Y, Theodose TA. Tree species composition, biodiversity and regeneration in response to catena shape and position in a mountain forest. Scandinavian Journal of Forest Research. 2017;32(1):80-90

Oksanen J. et al. Vegan: Community ecology package. [acesso em: 11 mar. de 2015]. Disponível em: http://cran.r-project.org/

Pitman NCA, Terborgh J, Silman MR, Percy Nunes V. Tree species distributions in an upper Amazonian forest. Ecology. 1999;80(8):2651-61.

Poorter L. Are species adapted to their regeneration niche, adult niche, or both? The American Naturalist. 2007;169(4)433-42.

R Development Core Team. R: A language and environment for statistical computing. [acesso em: 11 mar. de 2015]. Disponível em: http://www.Rproject.org [acesso em: 11 mar. de 2015].

Reitz P, Klein RM, Reis, A. Projeto madeira do Rio Grande do Sul. Sellowia, 1983(34-35):1-525.

Roberts DW. LABDSV: Ordination and Multivariate Analysis for Ecology. [acesso em: 11 mar. de 2015]. Disponível em: http://CRAN.Rproject.org/package $=$ labdsv

Rodrigues LA, Carvalho DA, Oliveira Filho AT, Curi N. Efeitos de solos e topografia sobre a distribuição de espécies arbóreas em um fragmento de Floresta Estacional Semidecidual, em Luminárias, MG. Revista Árvore. 2007;31(1):25-35.

Schupp EW, Milleron T, Russo SE. Dissemination limitation and the origin and maintenance of species rich tropical forests. In: Levey DJ, Silva WR, Galetti M, editors. Seed dispersal and frugivory: ecology, evolution and conservation. Wallingford: CAB International; 2002 p.1933. 
Scipioni MC, Longhi SJ, Araújo MM, Reinert DJ. Regeneração natural de um fragmento da Floresta Estacional Decidual na Reserva Biológica do Ibicuí-Mirim (RS). Floresta. 2009;39(3):675-90.

Silva AC, Van Den Berg E, Higuchi P, Oliveira Filho AT. Comparação florística de florestas inundáveis das regiões Sudeste e Sul do Brasil. Revista Brasileira de Botânica. 2007;30(2):257-69.

Souza K, Souza CC, Rosa MG, Cruz AP, Lima CL, Silva JO et al. Estrutura e estratégias de dispersão do componente arbóreo de uma floresta subtropical ao longo de uma topossequência no Alto-Uruguai. Scientia Forestalis.

2015;43(106):321-32.

Via S, Gomulkiewicz R, De Jong G, Scheiner SM, Schlichting CD, Van Tienderen PH. Adaptive phenotypic plasticity: consensus and controversy. Trends in Ecology and Evolution. 1995;10(5):212-7.

Volpato MML. Regeneração natural em uma floresta secundária no domínio de Mata Atlântica: uma análise fitossociológica [dissertação] Viçosa, MG: Universidade Federal de Viçosa; 1994. 